\title{
Dynamics of Fermentation Parameters and Bacterial Community in High-Moisture Alfalfa Silage with or without Lactic Acid Bacteria
}

\author{
Shanshan Zhao ${ }^{1,2}$, Fengyuan Yang ${ }^{1,2}$, Yuan Wang ${ }^{1,2}$, Xiaomiao Fan ${ }^{1,2}$, Changsong Feng ${ }^{3}$ and Yanping Wang ${ }^{1,2, *}$ \\ 1 Henan Key Laboratory of Ion Beam Bio-Engineering, College of Physics, Zhengzhou University, \\ Zhengzhou 450000, China; zsszd@gs.zzu.edu.cn (S.Z.); yangfy@gs.zzu.edu.cn (F.Y.); \\ wangyuany5@163.com (Y.W.); fanxiaomiao1125@163.com (X.F.) \\ 2 Henan Key Laboratory of Ion Beam Bio-Engineering, School of Agricultural Science, Zhengzhou University, \\ Zhengzhou 450000, China \\ 3 Institute of Animal Husbandry and Veterinary Science, Henan Academy of Agricultural Sciences, \\ Zhengzhou 450000, China; Fengchangsong72@163.com \\ * Correspondence: wyp@zzu.edu.cn; Tel.: +86-0371-67761726
}

check for updates

Citation: Zhao, S.; Yang, F.; Wang, Y.; Fan, X.; Feng, C.; Wang, Y. Dynamics of Fermentation Parameters and Bacterial Community in High-Moisture Alfalfa Silage with or without Lactic Acid Bacteria. Microorganisms 2021, 9, 1225. https: / / doi.org/10.3390/ microorganisms 9061225

Received: 17 May 2021

Accepted: 31 May 2021

Published: 4 June 2021

Publisher's Note: MDPI stays neutral with regard to jurisdictional claims in published maps and institutional affiliations.

Copyright: (c) 2021 by the authors. Licensee MDPI, Basel, Switzerland. This article is an open access article distributed under the terms and conditions of the Creative Commons Attribution (CC BY) license (https:// creativecommons.org/licenses/by/ $4.0 /)$.

\begin{abstract}
The aim of this study was to gain deeper insights into the dynamics of fermentation parameters and the bacterial community during the ensiling of high-moisture alfalfa. A commercial lactic acid bacteria (YX) inoculant was used as an additive. After 15 and 30 days of ensiling, the control silage (CK) exhibited a high $\mathrm{pH}$ and a high concentration of ammoniacal nitrogen $\left(\mathrm{NH}_{3}-\mathrm{N}\right)$; Enterobacter and Hafnia-Obesumbacterium were the dominant genera. At $60 \mathrm{~d}$, the $\mathrm{pH}$ value and the concentration of $\mathrm{NH}_{3}-\mathrm{N}$ in CK silage increased compared with 15 and $30 \mathrm{~d}$, propionic acid and butyric acid (BA) were detected, and Garciella had the highest abundance in the bacterial community. Compared with CK silage, inoculation of YX significantly promoted lactic acid and acetic acid accumulation and reduced $\mathrm{pH}$ and $\mathrm{BA}$ formation, did not significantly reduce the concentration of $\mathrm{NH}_{3}-\mathrm{N}$ except at $60 \mathrm{~d}$, and significantly promoted the abundance of Lactobacillus and decreased the abundance of Garciella and Anaerosporobacter, but did not significantly inhibit the growth of Enterobacter and Hafnia-Obesumbacterium. In conclusion, high-moisture alfalfa naturally ensiled is prone to rot. Adding $\mathrm{YX}$ can delay the process of silage spoilage by inhibiting the growth of undesirable microorganisms to a certain extent.
\end{abstract}

Keywords: alfalfa silage; bacterial community; fermentation quality; high moisture content; highthroughput sequencing; lactic acid bacteria

\section{Introduction}

Alfalfa is a perennial herbaceous legume. It is one of the most important legume forages in the world because of its good nutritional quality, high yield, and strong adaptability [1]. As a source of livestock protein, it can be the basic component in the rations of dairy cattle, beef cattle, horses, sheep, goats, and other livestock [2]. Ensiling has been regarded as a common way for preserving green forages. It is an anaerobic microbial-based fermentation process, dominated by lactic acid bacteria (LAB), which produce the lactic acid (LA) required for $\mathrm{pH}$ decline and inhibition of non-acid-resistant harmful microorganisms [3]. In contrast to corn and other cereal crops, alfalfa is considered a difficult silage crop, mainly because of its high buffer capacity and low concentration of water-soluble carbohydrate (WSC) [4]. When ensiled at moisture concentration $>700 \mathrm{~g} / \mathrm{kg}$ dry matter (DM), it can be a challenge to obtain good-quality silage as this dilutes the WSC concentration and $\mathrm{LAB}$ count, and counteracts a rapid drop in $\mathrm{pH}[5,6]$. Moreover, high-moisture silage often bears a high risk of effluent loss and clostridial fermentation, leading to high DM loss, extensive proteolysis, and high butyric acid (BA) production, which can reduce feed palatability $[7,8]$. Feeding silage of high BA content will reduce animal DM intake and 
clostridial endospores can even lead to clostridial contamination in milk [9]. In practice, field wilting is a traditional method to reduce water content. In this case, an additional loss may occur due to crushing loss and respiratory consumption. Moreover, the process depends entirely on weather conditions, which can be adverse if rainfall occurs during this period [10]. For example, in the main rain season (from late spring to summer) in East China, alfalfa with suitable water content is not easy to obtain [11]. When the lower WSC content and higher moisture content of raw materials introduce difficulties for natural ensiling, adding additives is one of the most commonly used methods to improve silage quality. At present, there are many kinds of silage additives used in the world, which can be divided into four categories: bacterial inoculants, chemicals, enzymes, and non-protein nitrogen [12]. Each of these additives has its own advantages and limitations. Adding organic acid directly is effective to improve silage quality, and some studies have been reported $[13,14]$. However, the higher initial cost compared with that of inoculants may be a barrier to adoption [12]. In addition, in order to spray organic acid evenly in the actual production process, especially in large farms, the machinery used may cause corrosion and also harm the safety of operators. Due to the generally recognized as safe (GRAS) status, $\mathrm{LAB}$ inoculants have become the effective tool to improve the microbial quality of silage by screening varieties with special characteristics [15]. Commercial LAB inoculants are frequently used to improve the ensiling process. Many types of homo-fermentative LAB, Enterococcus faecium, and Pediococcus spp. have been proposed as effective stimulants to reinforce LA fermentation [16,17]. LAB YX, as a special commercial LAB additive for alfalfa, has a good effect in improving the quality of alfalfa silage, but it is generally used in alfalfa silage with suitable moisture content. There are few reports about ensiling high-moisture alfalfa when adding LAB YX.

It is widely known that the silage process involves a variety of microbial communities and biochemical reactions. The quality of silage depends largely on the microbial community and its dynamic succession and fermentation metabolites [18]. A better understanding of the microbial community in silage is essential for improving silage quality, especially at high moisture content. In recent years, medium-independent methods have been developed for the analysis of microbial communities to avoid the limitations of traditional culture methods $[19,20]$. In this study, a next-generation sequencing (NGS) technique was used for studying bacterial communities.

The purpose of this study was to explore the dynamics of fermentation parameters and the bacterial community and the correlations among them in high-moisture naturally ensiled alfalfa, and to explore the effect of adding commercial LAB YX on the dynamic of fermentation parameters and the bacterial community. This will deepen understanding of the role of microorganisms in high-moisture alfalfa ensiling and provide more detailed information for alfalfa ensiling in a humid environment.

\section{Materials and Methods}

\subsection{Forage Harvest and Silage Preparation}

Fresh alfalfa was cultivated and harvested after rain at the early bloom stage in Zhengzhou, Henan Province, China (temperate monsoon climate, $34.76^{\circ} \mathrm{N}, 113.65^{\circ} \mathrm{E}$, altitude $110.4 \mathrm{~m}$ above sea level). The material was wilted for about $24 \mathrm{~h}$ to obtain a DM content of $266.03 \mathrm{~g} / \mathrm{kg}$ fresh matter (FM). The material was then chopped using a crop chopper into sections of approximately $1-2 \mathrm{~cm}$ in length. The $\mathrm{pH}, \mathrm{WSC}$, and high buffering capacity (BC) of fresh alfalfa were 6.06, $17.56 \mathrm{~g} / \mathrm{kg} \mathrm{DM}$, and $460 \mathrm{mEq} / \mathrm{kg} \mathrm{DM}$, respectively. The epiphytic LAB, coliform bacteria, and aerobic bacteria in the fresh alfalfa were 4.65 , 4.83, and $5.28 \log 10 \mathrm{cfu} \mathrm{g}^{-1} \mathrm{FM}$, respectively. To accurately trace the degradation of the organic acids before and after fermentation, laboratory vacuum-packed mini silos have been frequently used for alfalfa silage [21-23]. Approximately $500 \mathrm{~g}$ for each of three replicates of chopped alfalfa were packed into polyethylene plastic bags (dimensions: $200 \mathrm{~mm} \times 300 \mathrm{~mm}$; Dongda, Zhengzhou, China), vacuumed, and sealed with a vacuum sealer (P-290, Shineye, Dongguan, China). These were individually prepared for each of the 
following treatments: (a) control (CK), which was treated with no additive as natural silage and (b) LAB (YX), isolated from the Yaxin alfalfa ensiling additive (Yaxin Biotechnology Co., Ltd., Taiwan, China). The application rate of LAB of YX into the fresh forage was $1 \times 10^{6} \mathrm{cfu} \mathrm{g}^{-1} \mathrm{FM}$, and an equal volume of distilled water was sprayed onto the fresh alfalfa for the control group. The samples were ensiled for 15,30 , and $60 \mathrm{~d}$ at room temperature $\left(25^{\circ} \mathrm{C}\right)$.

\subsection{Analysis of Fermentation Parameters and Chemical Composition}

Immediately after the bags were opened, the subsamples (10 g) were blended with $90 \mathrm{~mL}$ of sterilized water. The $\mathrm{pH}$ was measured with an electrode $\mathrm{pH}$ meter (Mettler Toledo Co., Ltd., Greifensee, Switzerland). The ammoniacal nitrogen $\left(\mathrm{NH}_{3}-\mathrm{N}\right)$ level was determined using Berthelot colorimetry [24]. The concentrations of organic acids, LA, acetic acid (AA), propionic acid (PA), and BA were measured using a high-performance liquid chromatography system (Waters Inc., MA, USA; column: Carbomix H-NP 10:8\% $(7.8 \times 300 \mathrm{~mm} \times 10 \mu \mathrm{m})$, Sepax Technologies, Inc., Santa Clara, CA, USA; detector: UV detector; Waters Inc.; eluent: $0.0254 \% \mathrm{H}_{2} \mathrm{SO}_{4}, 0.6 \mathrm{~mL} \mathrm{~min}^{-1}$; temperature: $55^{\circ} \mathrm{C}$ ) [25]. The DM weights of the fresh alfalfa and silage materials were determined following oven drying at $65{ }^{\circ} \mathrm{C}$ for $48 \mathrm{~h}$. The oven-dried samples were then milled through a $1.0 \mathrm{~mm}$ sieve prior to further chemical analyses. The WSC was determined by anthrone colorimetry [26]. The BC was determined using the hydrochloric acid-sodium hydroxide method [27]. The neutral detergent fiber (NDF), acid detergent fiber (ADF), and acid detergent lignin (ADL) concentrations were determined according to Van Soest et al. [28], using a CXC-6 crude fiber analyzer (Zhejiang Top Instrument Co., Ltd., Zhejiang, China). Hemicellulose and cellulose concentrations were estimated indirectly as $[\mathrm{NDF}-\mathrm{ADF}]$ and $[\mathrm{ADF}-\mathrm{ADL}]$, respectively.

\subsection{Bacterial Community Analyses}

Subsamples (10 g) of each fresh or silage sample were shaken well with $90 \mathrm{~mL}$ of sterile phosphate buffer saline at $180 \mathrm{rpm}$ for $1 \mathrm{~h}$. The solution was filtered through four layers of medical gauze and the filtrates centrifuged at $8000 \times g$ for $15 \mathrm{~min}$ at $4{ }^{\circ} \mathrm{C}$ to collect the microbial pellet for DNA extraction [29]. Total DNA was extracted via a Bacterial DNA Kit D3350-02 (Omega Biotek, Norcross, GA, USA). After DNA extraction, DNA concentration was evaluated by $1 \%$ agarose gel electrophoresis. The $16 \mathrm{~S}$ rRNA genes of distinct regions (16S V4) were amplified using the forward primer 515F (GTGCCAGCMGCCGCGGTAA) and reverse primer 806R (GGACTACHVGGGTWTCTAAT). The resulting PCR products were extracted from a $\%$ agarose gel and further purified using a GeneJET Gel Extraction Kit (Thermo Fisher Scientific Inc., Carlsbad, CA, USA). The amplicon sequencing of 16S rDNA was conducted using Thermo Fisher's Ion S5 ${ }^{\mathrm{TM}}$ XL (Biomarker Technologies Corporation, Beijing, China). The NGS reads were assembled using FLASH (version 1.2.11) and low-quality reads were removed according to the QIIME quality control process (version 1.9.1). Sequence analyses were performed via Uparse software (v7.0.1001). A 97\% similarity cutoff was used to define operational taxonomic units (OTUs).

\subsection{Statistical Analyses}

The data of fermentation parameters were statistically analyzed using the GLM procedure of IBM SPSS version 22.0 (SPSS Inc., Chicago, IL, USA). Statistical differences in parameters among the days were determined in accordance with Duncan's multiple comparison test, and effects were considered significant when $p<0.05$. The alpha diversities of samples, the Shannon index, and Chao richness estimator were determined using Mothur (version 1.30.1, http: / / www.mothur.org/wiki/Classify.seqs accessed on 24 August 2020). Taxonomic classification at different levels was performed using the Ribosome Database Project (version 2.2, http:/ / sourceforge.net/projects / rdpclassifier / accessed on 24 August 2020) algorithm to classify the representative sequences of each OTU. Linear discriminant analysis effect size (LEfSe) analysis (Galaxy Version 1.0, https: / / huttenhower.sph.harvard.edu/galaxy/ accessed on 24 August 2020) was conducted to 
determine the differentially abundant taxonomies among different treatments by coupling one-way analysis of variance with a non-parametric factorial Wilcoxon sum-rank test for statistical significance using Python (version 2.7, https:/ /www.python.org accessed on 24 August 2020). Non-metric multidimensional scaling (NMDS) analysis and a Spearman correlation heatmap based on the Spearman correlation coefficients among the bacterial community and fermentation parameters were produced using $\mathrm{R}$ software (version 2.15.3).

The derived variable regions of $16 \mathrm{~S}$ rRNA gene sequence datasets were submitted to the NCBI under the BioProject accession number PRJNA720220.

\section{Results}

3.1. Changes in Fermentation Parameters in Silages during Ensiling with or without LAB

Changes in fermentation parameters in silages during ensiling with or without LAB are shown in Figure 1. In the natural silage (CK), neither $\mathrm{pH}$ nor $\mathrm{NH}_{3}-\mathrm{N}$ concentration differed between 15 and $30 \mathrm{~d}$, but increased $(p<0.05)$ greatly at $60 \mathrm{~d}$ compared with $30 \mathrm{~d}$. The LA concentration and LA/AA peaked at $15 \mathrm{~d}$, then declined, and were significantly $(p<0.05)$ lower at $60 \mathrm{~d}$ than at $30 \mathrm{~d}$. The AA concentration significantly $(p<0.05)$ increased with longer ensiling time. The WSC concentration decreased rapidly during $15 \mathrm{~d}$ of ensiling, and then remained at $3.62 \mathrm{~g} / \mathrm{kg}$ DM at $60 \mathrm{~d}$. Both PA and BA were detected at $60 \mathrm{~d}$, with concentrations of 29.73 and $37.13 \mathrm{~g} / \mathrm{kg}$ DM, respectively.
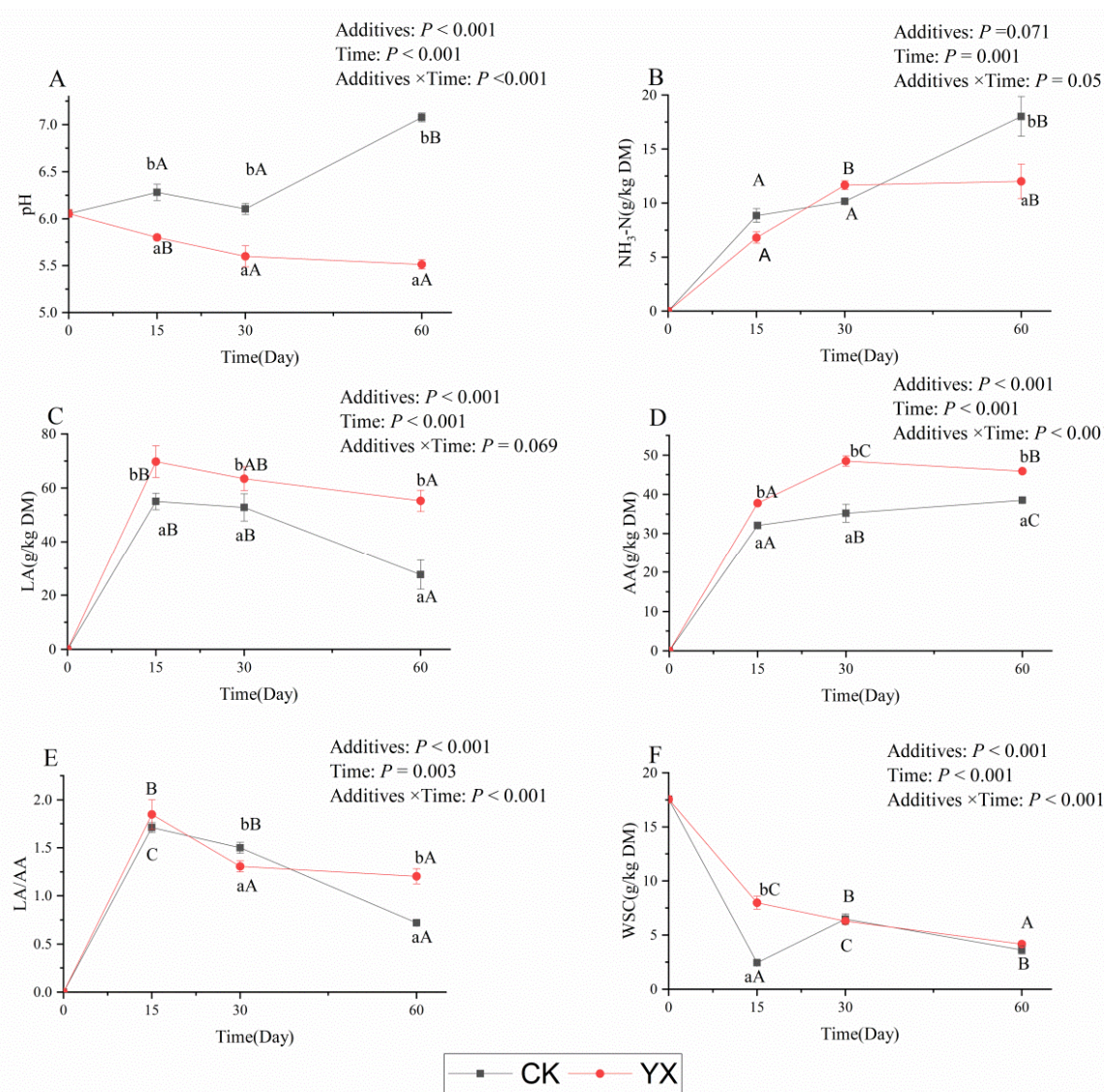

Figure 1. Changes in fermentation parameters ((A): $\mathrm{pH}$ value; (B): $\mathrm{NH}_{3}-\mathrm{N} ;(\mathbf{C})$ : $\mathrm{LA}$; (D): AA; (E): LA/AA; (F): WSC) in alfalfa silages during ensiling for $60 \mathrm{~d}$. Values with different superscript lowercase letters show significant differences among treatments on the same ensiling day, values with different superscript capital letters show significant differences among ensiling days in the same treatment $(p<0.05)$. $\mathrm{CK}$, control; $\mathrm{YX}$, inoculated with commercial $\mathrm{LAB}_{\mathrm{YX}}$; $\mathrm{NH}_{3}-\mathrm{N}$, ammoniacal nitrogen; LA, lactic acid; AA, acetic acid; LA/AA, the ratio of lactic acid to acetic acid; WSC, water-soluble carbohydrate.

In the YX silage, the $\mathrm{pH}$ and WSC concentration gradually decreased with longer ensiling time; the $\mathrm{NH}_{3}-\mathrm{N}$ concentration increased significantly $(p<0.05)$ from the beginning 
to $30 \mathrm{~d}$ and there was no significant $(p>0.05)$ change from 30 to $60 \mathrm{~d}$. The LA concentration and LA/AA value rapidly increased up to $15 \mathrm{~d}$ and then decreased; the AA content significantly $(p<0.05)$ increased up to $30 \mathrm{~d}$ and then significantly $(p<0.05)$ decreased by $60 \mathrm{~d}$. No BA was detected in YX silage.

Compared with CK silage, the $\mathrm{pH}$ of $\mathrm{YX}$ silage was significantly $(p<0.05)$ lower, and the LA and AA concentrations were significantly $(p<0.05)$ higher in all ensiling periods. At $60 \mathrm{~d}$, the $\mathrm{NH}_{3}-\mathrm{N}$ concentration of $\mathrm{YX}$ silage was significantly $(p<0.05)$ lower than of $\mathrm{CK}$ silage at $60 \mathrm{~d}$. The LA/AA of YX silage was significantly $(p<0.05)$ lower than of CK silage at $30 \mathrm{~d}$, but significantly $(p<0.05)$ higher at $60 \mathrm{~d}$.

Changes in DM and structural carbohydrates in silages during ensiling with or without $\mathrm{LAB}$ are shown in Figure 2. In the CK silage, the DM content did not change significantly during $30 \mathrm{~d}$ of ensiling, but was greatly reduced $(p<0.05)$ at $60 \mathrm{~d}$. Compared with CK silage, the YX silage had significantly higher DM content at $60 \mathrm{~d}$, significantly lower ADL and cellulose content at each ensiling time, significantly lower NDF content at 15 and $60 \mathrm{~d}$, significantly lower ADF content at 30 and $60 \mathrm{~d}$, and significantly lower hemicellulose content at $15 \mathrm{~d}(p<0.05)$.
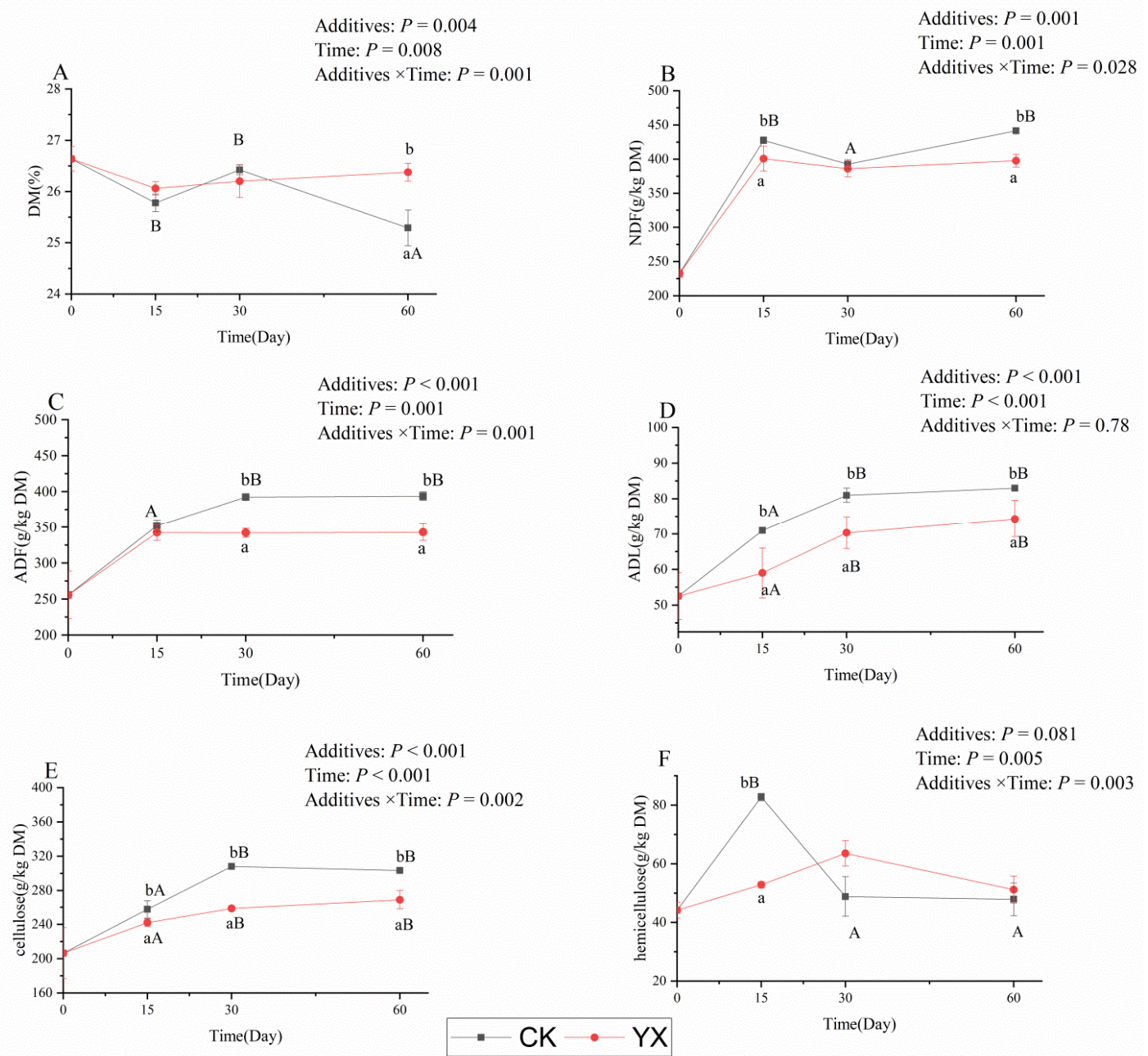

Figure 2. Changes in DM (A), NDF (B), ADF (C), ADL (D), cellulose (E), and hemicellulose (F) in alfalfa silages during ensiling for $60 \mathrm{~d}$. Values with different superscript lowercase letters show significant differences among treatments on the same ensiling day, values with different superscript capital letters show significant differences among ensiling days in the same treatment $(p<0.05)$. CK, control; YX, inoculated with commercial LAB YX; DM, dry matter; NDF, neutral detergent fiber; ADF, acid detergent fiber; ADL, acid detergent lignin. 


\subsection{Changes in Bacterial Community in Silages during Ensiling with or without LAB}

High-throughput analyses were used to detect the bacterial diversity of the alfalfa silages at 15, 30, and $60 \mathrm{~d}$. The average number of reads per sample was 84,194 , and the average number of effective data was 79,478 . The effective rate of quality control was $94.48 \%$. Using $97 \%$ identity, the sequences were clustered into 265 OTUs. The Chao and Shannon indexes were used to represent richness and diversity indices of the bacterial communities, respectively. There was no significant $(p>0.05)$ change in the richness of the bacterial community before and after ensiling, and the diversity of the bacterial community significantly $(p<0.05)$ decreased after ensiling (Figure 3A,B). In the CK silage, there was no significant $(p>0.05)$ change in bacterial community richness during ensiling; the diversity of the bacterial community was significantly lower at $60 \mathrm{~d}$ compared with 15 and $30 \mathrm{~d}$. The richness of the bacterial community of YX silage was similar to that of CK silage. Compared with CK silage, the bacterial community diversity of YX silage was lower at $30 \mathrm{~d}(p<0.05)$, but there was no significant difference between the two at 15 and $60 \mathrm{~d}$.

A

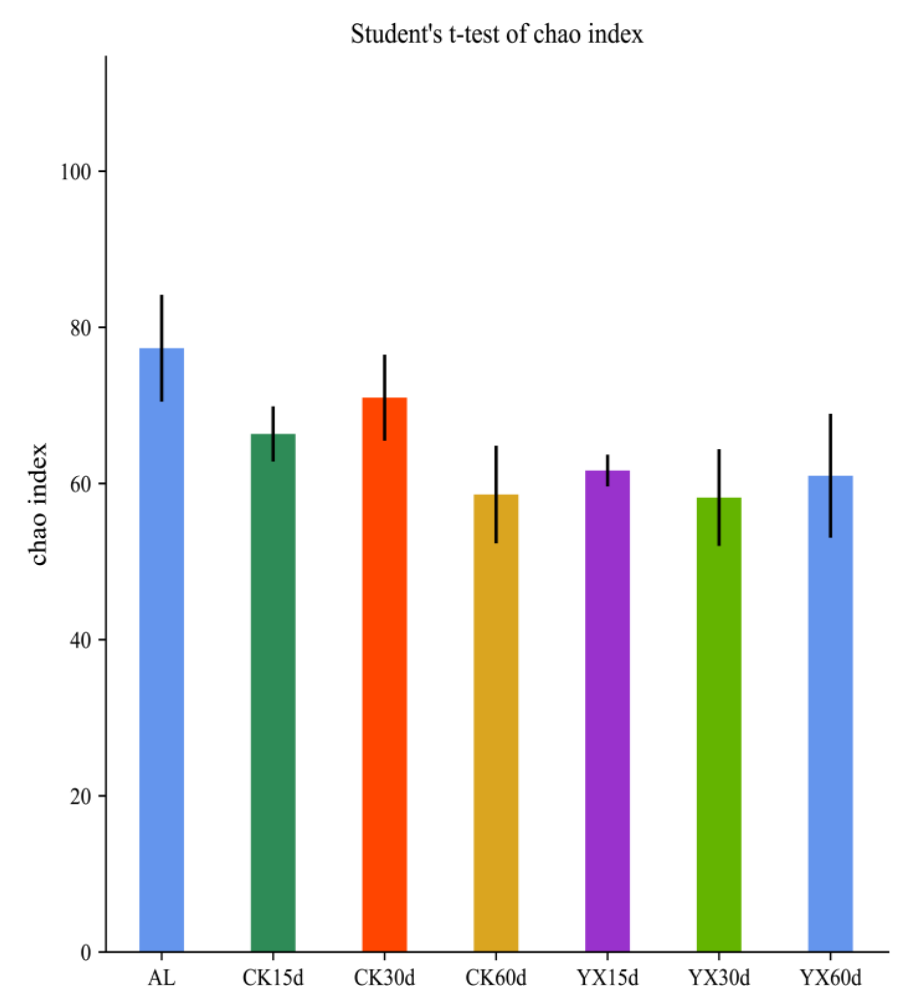

B

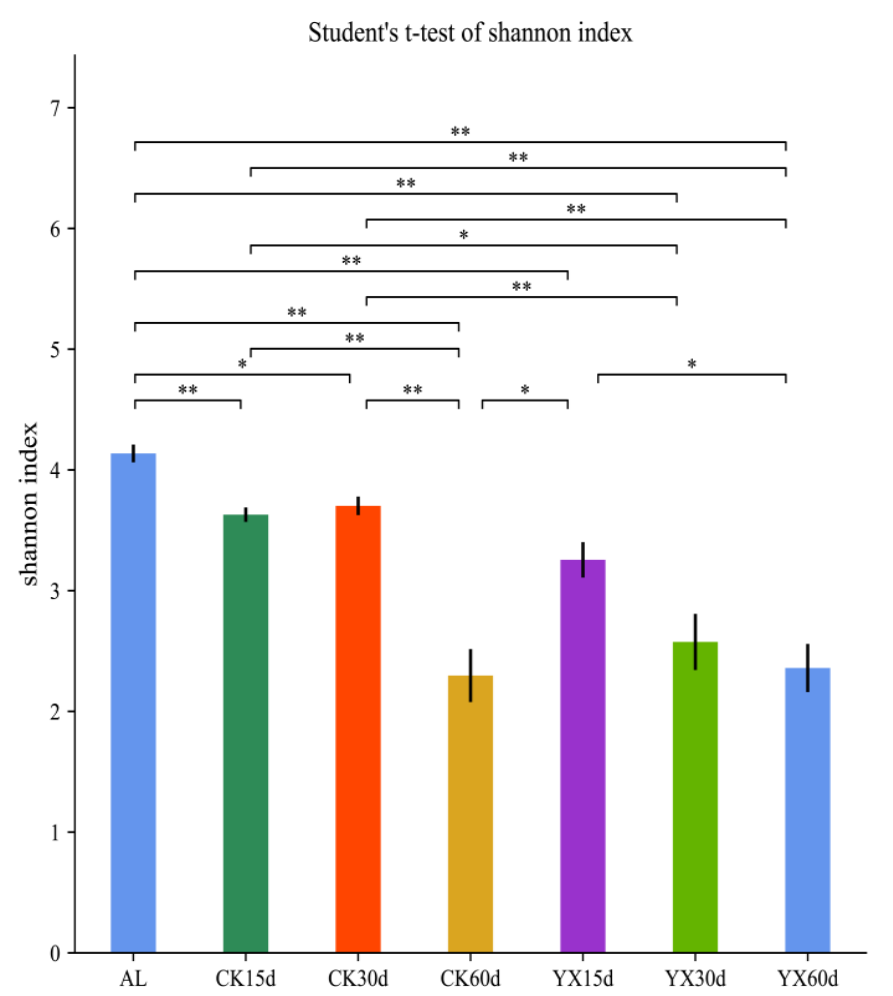

Figure 3. Bar plots of Chao indices (A) and Shannon indices (B) of bacterial communities in alfalfa silage. AL, alfalfa material before ensiling; $\mathrm{CK}$, control; $\mathrm{YX}$, inoculated with commercial LAB YX; the numbers following CK and $\mathrm{YX}$ stand for ensiled days of silage. ${ }^{*} p<0.05 ;{ }^{* *} p<0.01$.

After ensiling, the variance of the bacterial community structure was demonstrated by NMDS. There was distinct separation between the fresh materials and treated silages (Figure 4). The clear separation between CK and YX silages indicated that the distribution of the bacterial community was shifted by LAB inoculations. The samples at $60 \mathrm{~d}$ could be separated from the samples at 15 and $30 \mathrm{~d}$ in CK silage. The distribution of the bacterial communities was similar among the three silage periods in $\mathrm{YX}$ silage. 


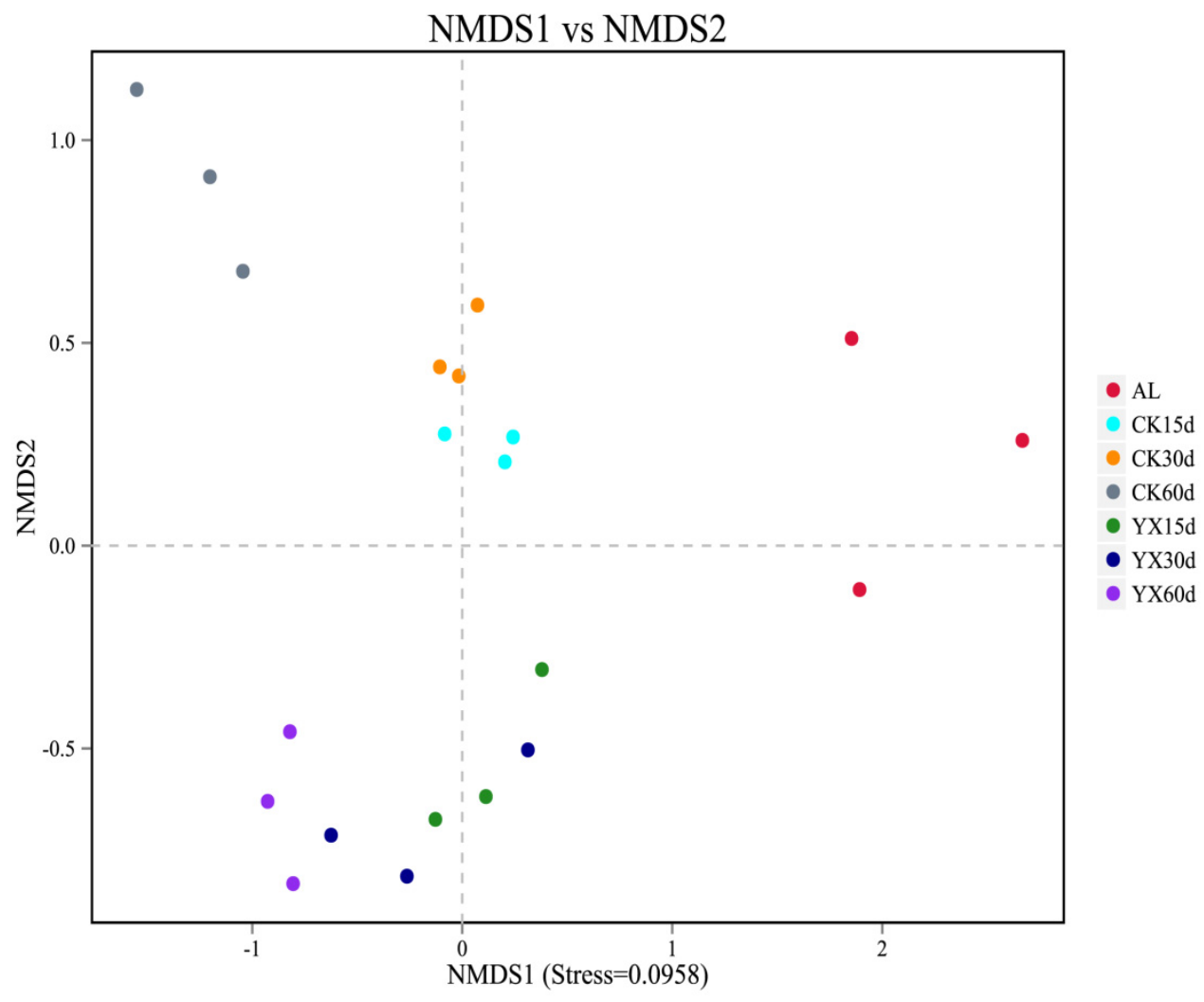

Figure 4. Non-metric multidimensional scaling (NMDS) plot based on OTU level in alfalfa silage. AL, alfalfa material before ensiling; $\mathrm{CK}$, control; $\mathrm{YX}$, inoculated with commercial LAB YX; the numbers following $\mathrm{CK}$ and $\mathrm{YX}$ stand for ensiled days of silage.

The bacterial community structures of pre-ensiled and silage samples at the phylum and genus levels are shown in Figure 5. The phyla Proteobacteria (55.71\%), Firmicutes (27.37\%), and Actinobacteria (16.87\%) were the main epiphytic bacteria in fresh materials (Figure 5A). In the CK silage, Proteobacteria and Firmicutes were the predominant phyla; with increased ensiling time, the relative abundance of Proteobacteria decreased, while that of Firmicutes increased. Compared with CK silage, the relative abundance of Firmicutes in YX silage was higher at 15 and $30 \mathrm{~d}$, and no different at $60 \mathrm{~d}$.

Genera Enterobacter (33.93\%), Pseudomonas (16.67\%), and Pantoea (7.09\%) dominated the epiphytic bacterial community of alfalfa (Figure 5B). A low abundance of LAB species was exhibited in the alfalfa epiphytic bacterial community, including Lactobacillus (1.35\%), Weissella (0.74\%), and Lactococcus (0.07\%). After ensiling, completely different microbial community dynamics were observed in CK and YX silages. In the CK silage, after $15 \mathrm{~d}$ of ensiling, the dominant microbial genera were Enterobacter (29.68\%), followed by HafniaObesumbacterium (19.71\%), Weissella (13.14\%), Lelliottia (11.05\%), and Lactococcus (9.46\%); Enterobacter ( $37.00 \%)$ peaked at $30 \mathrm{~d}$ and was lower at $60 \mathrm{~d}$. With increasing time of ensiling, the relative abundances of Hafnia-Obesumbacterium, Lelliottia, Weissella, and Lactococcus declined, and Garciella and Anaerosporobacter increased; Garciella became the dominant genus at $60 \mathrm{~d}$, with relative abundance of 59.26\%. In the YX silage, Lactobacillus increased continuously during the ensiling process, and peaked $(64.76 \%)$ at $60 \mathrm{~d}$; proportions of Enterobacter and Hafnia-Obesumbacterium decreased from 15 to $60 \mathrm{~d}$; the relative abundance of Garciella reached $9.88 \%$ at $60 \mathrm{~d}$. 

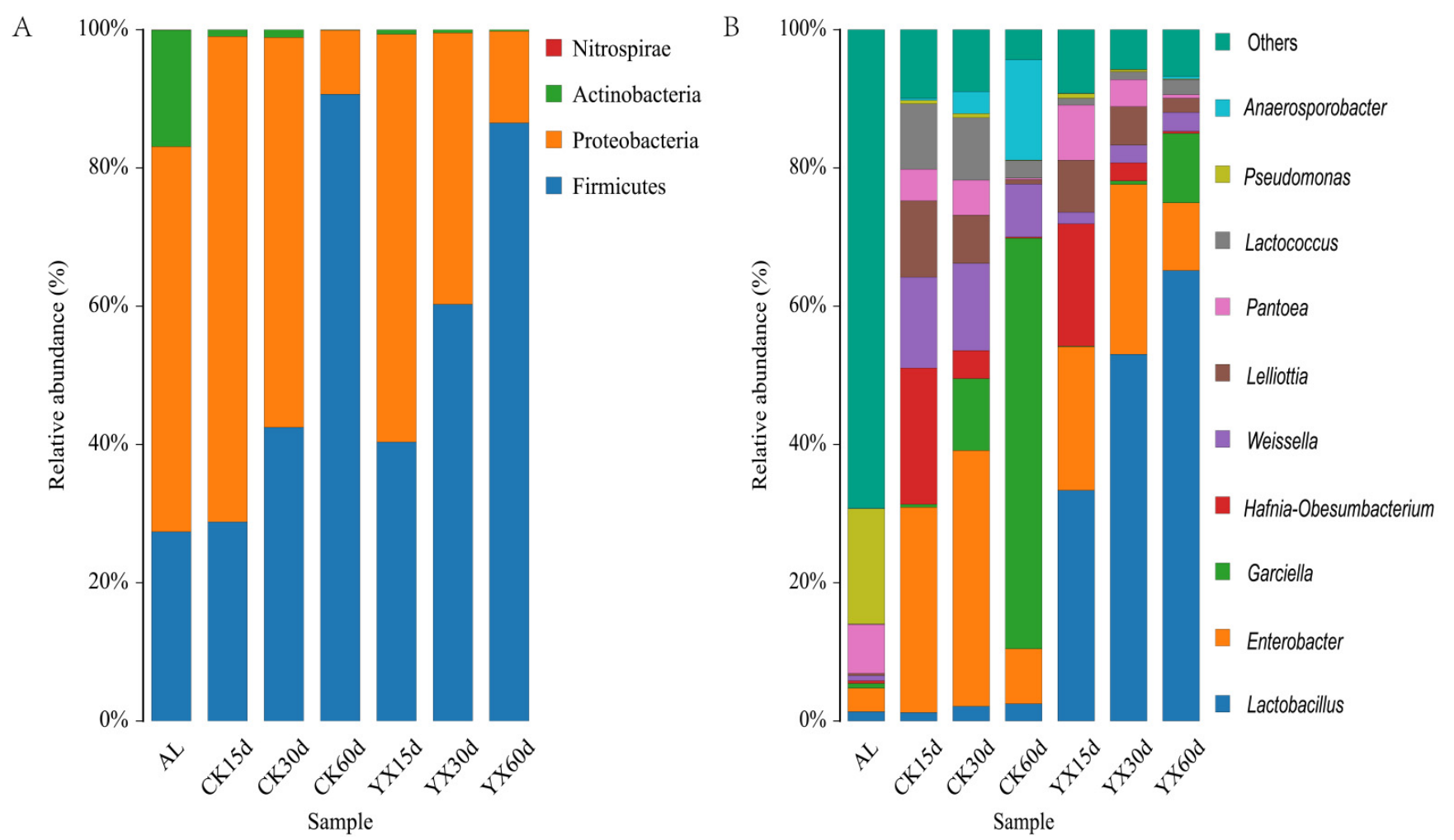

Figure 5. Bar plots of bacterial community and relative abundances by phylum (A) and genus (B) in alfalfa silage. AL, alfalfa material before ensiling; CK, control; $Y X$, inoculated with commercial LAB YX; the numbers following CK and YX stand for ensiled days of silage.

The LEfSe analysis was used to identify the taxa that most likely explained the differences in bacterial community structures between the CK and YX silages after 15, 30, and $60 \mathrm{~d}$ of ensiling (Figure 6). Compared with CK silage, YX silage had significantly higher abundance of Lactobacillus at each ensiling time and significantly higher abundance of Enterococcus at $60 \mathrm{~d}$, but had significantly lower relative abundance of Weissella at each ensiling time, significantly lower abundance of Lactococcus and Lelliottia at $15 \mathrm{~d}$, and significantly lower abundance of Garciella and Anaerosporobacter at 30 and $60 \mathrm{~d}$ (all $p<0.05$ ).

A

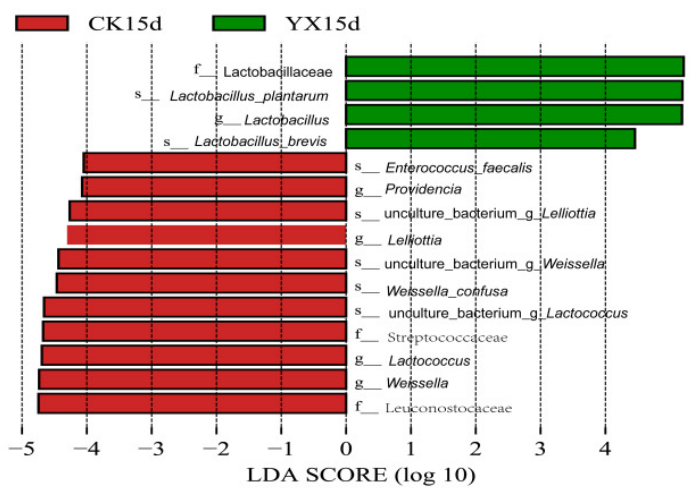

Figure 6. Cont. 
$\mathrm{B}$

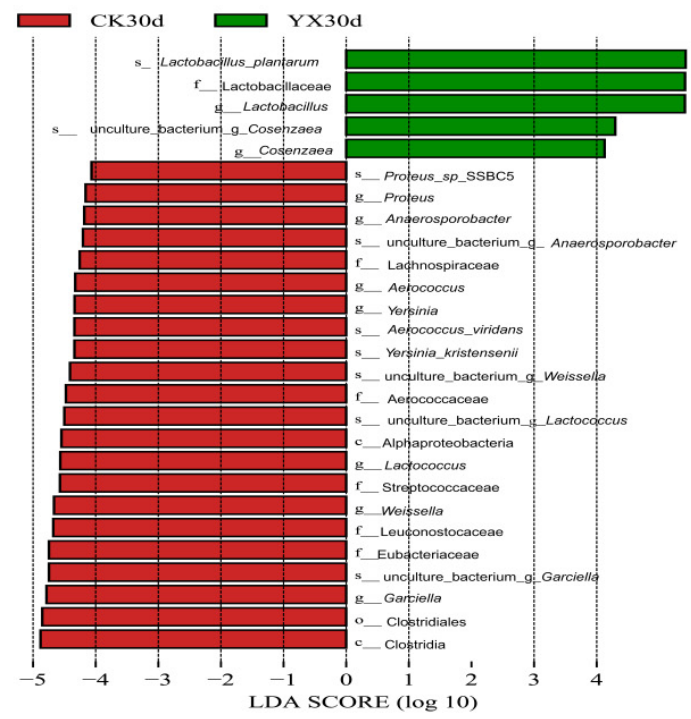

C

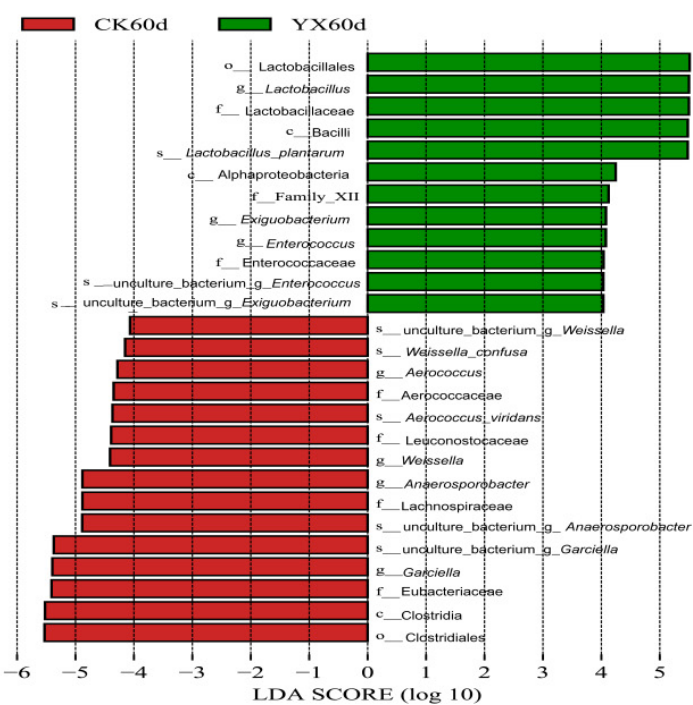

Figure 6. Comparison of microbial variations using LEfSe analysis for $15 \mathrm{~d}(\mathbf{A}), 30 \mathrm{~d}(\mathbf{B})$, and $60 \mathrm{~d}(\mathbf{C})$. CK, control; YX, inoculated with commercial LAB YX; the numbers following CK and YX stand for ensiled days of silage.

\subsection{Relationships between Fermentation Parameters and Bacterial Community}

Spearman's correlations were used to study the relationships among the top 10 most abundant genera and fermentation parameters (Figure 7). At $15 \mathrm{~d}, \mathrm{pH}$ was positively correlated with Weissella and Glutamicibacter and negatively correlated with Lactobacillus $(p<0.05)$; LA was positively correlated with Lactobacillus and negatively correlated with Weissella, Glutamicibacter, and Enterobacter (Figure 7A). There were positive correlations between $\mathrm{NH}_{3}-\mathrm{N}$ and two genera $(p<0.05)$, Klebsiella and Lelliottia (Figure 7A). At $60 \mathrm{~d}, \mathrm{pH}$ was positively correlated with Garciella and Anaerosporobacter and negatively correlated with Lactobacillus and Enterococcus ( $p<0.05)$; LA was positively correlated with Lelliottia and Pediococcus and negatively correlated with Anaerosporobacter $(p<0.05)$ (Figure 7B). $\mathrm{NH}_{3}-\mathrm{N}$ was positively correlated with Garciella and Anaerosporobacter and negatively correlated with Lactobacillus; BA was positively correlated with Garciella, Anaerosporobacter, Clostridium_sensu_stricto_18, and Weissella and negatively correlated with Lactobacillus, Enterococcus, and Pediococcus $(p<0.05)$ (Figure 7B). 

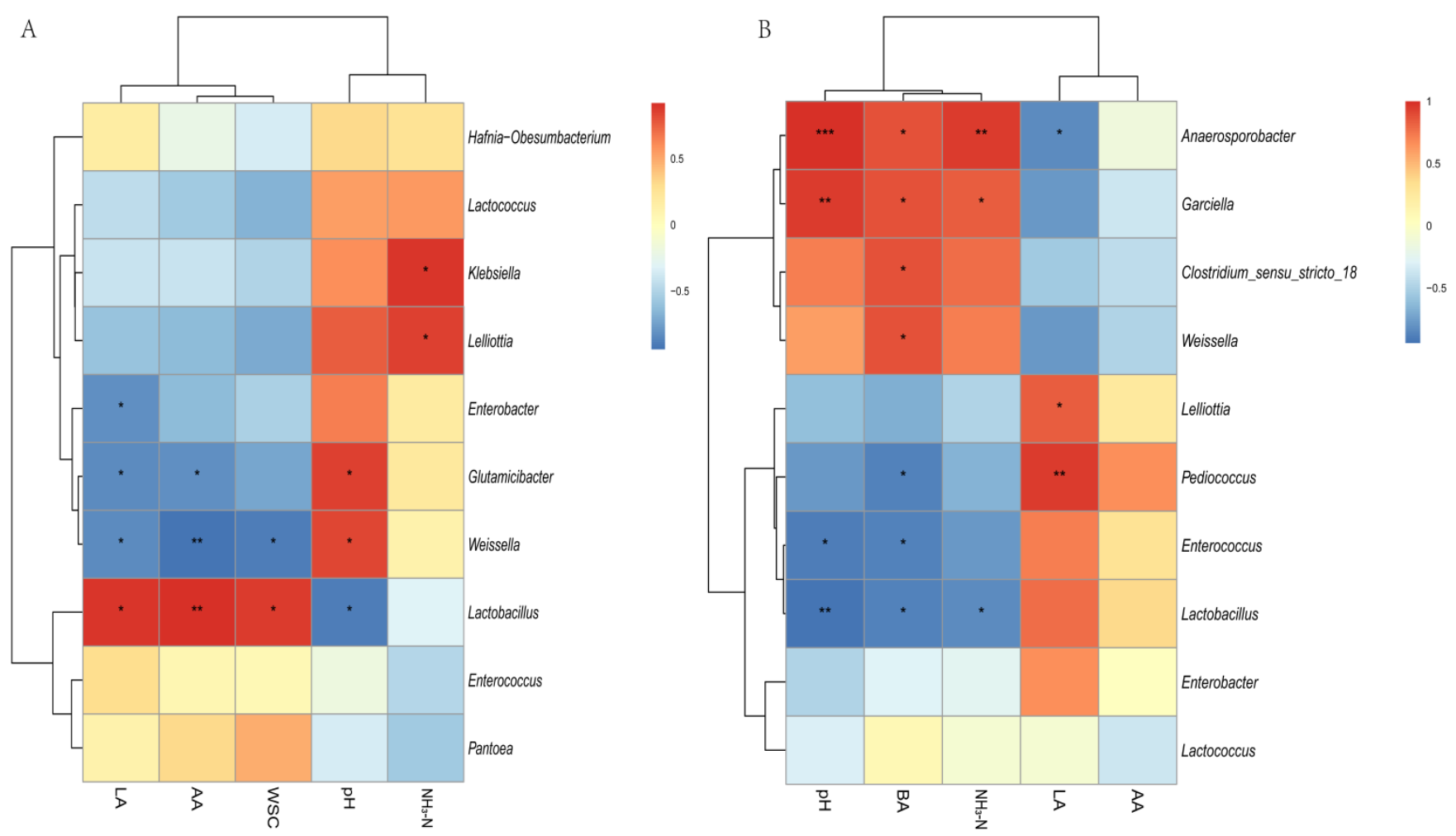

Figure 7. Spearman correlation heatmap of abundance of the top 10 abundant bacterial genera and fermentation properties in alfalfa silage for $15 \mathrm{~d}(\mathrm{~A})$ and $60 \mathrm{~d}(\mathrm{~B})$. LA, lactic acid; AA, acetic acid; BA, butyric acid; $\mathrm{NH}_{3}-\mathrm{N}$, ammoniacal nitrogen; WSC, water-soluble carbohydrate. ${ }^{*} p<0.05 ;{ }^{* *} p<0.01 ;{ }^{* *} p<0.001$.

\section{Discussion}

Generally, LAB is the main microbial inoculum affecting silage fermentation, because it can produce organic acids responsible for silage preservation; the LAB count must exceed $10^{5} \mathrm{cfu} / \mathrm{g}$ FM for optimum silage preservation [30]. In this study, fresh material showed chemical characteristics associated with poor silage quality, such as high $\mathrm{BC}$, high moisture content, small numbers of epiphytic LAB, and low WSC content. These results showed that the alfalfa used was difficult to naturally ensile.

\subsection{Changes in Fermentation Parameters, DM, and Structural Carbohydrates in Silages during Ensiling with or without $L A B$}

Both $\mathrm{pH}$ and organic acids are important indicators to ensure silage quality. Previous studies reported that high moisture content was unfavorable for natural ensiling, leading to decreased organic acid concentration, increased $\mathrm{pH}$, and a detrimental effect on the fermentation process for alfalfa silage [17,31]. In this study, the $\mathrm{pH}$ of $\mathrm{CK}$ silage increased rapidly to 7.07 at $60 \mathrm{~d}$, which was related to insufficient LA fermentation and accumulation of $\mathrm{NH}_{3}-\mathrm{N}$ during the ensiling process. However, the $\mathrm{pH}$ of $\mathrm{YX}$ silage was significantly lower than that of $\mathrm{CK}$ silage at all silage stages, consistent with the results showing higher LA content of YX silage than of CK silage in all silage stages. The results showed that LAB as a silage additive accelerated the accumulation of LA and reduced the $\mathrm{pH}$ of the silage environment. Yang et al. also reported a similar effect of LAB as a silage additive, in which adding LAB in alfalfa silage accelerated the process of LA fermentation [18]. Although inoculation with LAB enhanced LA fermentation compared with CK silage, $\mathrm{pH}$ in the $\mathrm{YX}$ silage greatly exceeded the ideal level $(<4.20)$ [32]. One possible reason for this was that the lack of WSC and high BC in alfalfa led to insufficient LA fermentation. In addition, for well-preserved silage, BA concentration should be $<10 \mathrm{~g} / \mathrm{kg} \mathrm{DM}$, with BA usually produced by Clostridia [33]. In this study, the BA concentration in CK silage was $>10 \mathrm{~g} / \mathrm{kg}$ $\mathrm{DM}$ at $60 \mathrm{~d}$, indicating that the natural ensiling was unsatisfactory. 
$\mathrm{NH}_{3}-\mathrm{N}$ is generally considered to be the result of amino acid deamination and decarboxylation, which reduce the nutritional value of silage in the ensiling process [34]. At $60 \mathrm{~d}$, the CK silage became putrid, a pungent odor was released when silage bags were opened, and the texture was sticky and smooth; compared with $\mathrm{CK}$ silage at $30 \mathrm{~d}$, the $\mathrm{pH}$ and $\mathrm{NH}_{3}-\mathrm{N}$ concentration were much higher, as was LA and WSC consumption, and BA was also detected. This is consistent with the typical characteristics of Clostridia fermentation. Kung et al. reported that the effects of plant and microorganism proteolytic enzymes may be typical causes of $\mathrm{NH}_{3}-\mathrm{N}$ accumulation [35]. The $\mathrm{NH}_{3}-\mathrm{N}$ concentration of $\mathrm{YX}$ silage at 15 and $30 \mathrm{~d}$ was not significantly $(p<0.05)$ lower compared with CK silage. One of the reasons may be that most plant protein hydrolases in alfalfa silage showed high activities at $\mathrm{pH}$ 5.0-6.0 [36], and the $\mathrm{pH}$ value of $\mathrm{YX}$ silage was in this range. In addition, another possible reason was that the inhibition of LAB of YX on proteolytic microorganisms was weak in these two silage stages. The DM was significantly $(p<0.05)$ lower in CK than in $\mathrm{YX}$ silage at $60 \mathrm{~d}$, and may be because BA fermentation was greater in CK than in $\mathrm{YX}$ silage, resulting in greater DM loss of CK silage-a similar outcome was found by Liu [31]. In the present study, the structural carbohydrate degradation curve showed that LAB played a role in lignocellulose degradation to improve the fermentation quality of silage, which was similar to our previous research results [25]. A marked reduction in ADL and cellulose concentration occurred in the YX silage in all silage periods, probably because the higher organic acid accumulation in the YX silage promoted acid hydrolysis of the ADL and cellulose.

\subsection{Changes in Bacterial Community in Silages during Ensiling with or without LAB}

In this study, the diversity of the bacterial community of alfalfa silage was lower than that of fresh material, and may be due to the large increase in some bacteria with good adaptability to the conditions of ensiling. Similar trends were also reported by Zheng et al. [17]. The Shannon indexes were similar between the CK and YX silages at $60 \mathrm{~d}$, and were lower in both silage groups than at 15 and $30 \mathrm{~d}$. This may be related to the significant dominance of Garciella in CK silage and Lactobacillus in YX silage at $60 \mathrm{~d}$.

The NMDS showed clear separation in bacterial community composition between fresh material and alfalfa silages (Figure 4). Ni et al. and Yang et al. also reported significant changes in microbial communities of fresh material and silage, and found that microbial communities of silage could not be predicted by those in fresh material because some species in fresh material were inhibited or inactivated during the ensiling process [18,37]. Divisions in our plots representing silage with or without inoculant indicated that LAB inoculation clearly changed the distribution of the bacterial community, consistent with differences in fermentation quality between the two silage groups [38].

Among many factors that can affect the fermentation process of silage, the dominant microbial species often determine the silage quality [39]. Therefore, analyzing the changes in fermentation parameters and microbial composition during ensiling is helpful in understanding the silage process and for improving silage quality [40]. In this study, Proteobacteria were the most abundant bacteria in the pre-ensiled samples and $15 \mathrm{~d}$ silage. Proteobacteria play a significant role in organic matter degradation and carbon and nitrogen cycling during anaerobic digestion [41]. However, Firmicutes replaced Proteobacteria as the dominant phylum at $60 \mathrm{~d}$. Bao et al. reported a similar result for silage of the legume Medicago [42]. Keshri et al. concluded that low $\mathrm{pH}$ or anaerobic conditions during ensiling favored the growth of species of Firmicutes, similar to our study in which Firmicutes was prevalent after $60 \mathrm{~d}$ of ensiling [43].

During ensiling, LAB play an important role in silage fermentation. In this study, fresh alfalfa had a high moisture content and low relative abundance of epiphytic LAB. Therefore, adding LAB was an effective way to improve quality of alfalfa silage. Different species and characteristics of LAB may affect the fermentation process [44]. In this study, the major LAB after ensiling were Lactobacillus, Lactococcus, and Weissella; among these, Lactobacillus plays a key role in silage fermentation. It can produce LA, reduce $\mathrm{pH}$, reduce 
the relative abundance of undesirable bacteria, and often becomes a dominant genus in various high-quality silages $[45,46]$. In this study, the relative abundance of Lactobacillus in the natural silage group was very low during the whole silage period, and adding LAB of YX significantly $(p<0.05)$ increased the Lactobacillus abundance with longer silage time, consistent with the higher LA concentration and lower $\mathrm{pH}$ in $\mathrm{YX}$ than in CK silage, indicating that adding LAB of $Y X$ had a positive effect on fermentation quality. We speculate that the increased Lactobacillus is likely to be the LAB YX strain, but unfortunately, this study cannot accurately determine the proportion of LAB YX in Lactobacillus, because NGS, which was used in our study, can only classify and identify microorganisms to genus level [47]. Lactococcus and Weissella are cocci-shaped LAB, and can initiate LA fermentation in the early stage of ensiling [30]. After the onset of ensiling, the main LAB in the CK silage were Lactococcus and Weissella, and their relative abundances were much higher than those in the YX silage. This is possibly because Lactococcus and Weissella were early colonizers, and could grow faster under ensiling conditions. Yang also reported that Lactococcus and Weissella started LA fermentation and grew vigorously during the early stage of ensiling in untreated silage [48]. However, Lactococcus and Weissella in YX silage could be outcompeted by Lactobacillus due to adding LAB of YX. Yang et al. made a similar report in which Lactobacillus outnumbered all other genera after inoculation with Lactobacillus plantarum [18]. Enterobacteriaceae are generally considered to be undesirable during silage because they can ferment LA into AA and other products, resulting in nutritional loss [37]. Enterobacteriaceae can survive in low $\mathrm{pH}$ environments and compete with LAB for WSC [49]. In our study, the relative abundance of Enterobacteriaceae, including Enterobacter, Hafnia-Obesumbacterium, and Lelliottia exceeded 38.8\% in both silage groups at 15 and $30 \mathrm{~d}$. Compared with CK silage, adding LAB of YX did not significantly reduce the abundance of Enterobacter and Hafnia-Obesumbacterium, possibly due to a large number of Enterobacteriaceae on the surface of fresh alfalfa. Therefore, in practical application, it is better to consider the dose-response and/or the inter-relationship between indigenous bacteria and the LAB YX added. Additionally, this was also related to the limitation of acid production ability of LAB of YX under conditions of high moisture content and low WSC; the weak inhibitory effect of LAB of YX on Enterobacteriaceae may also be another reason. Therefore, despite adding LAB of YX, Lactobacillus could not quickly become absolutely dominant in the community. Similar results were reported by Guo et al. in which Enterobacter was one of the two dominant bacteria after ensiling, especially in LABtreated silage [50]. In our study, the improvement effect of LAB of YX on the silage quality of high-moisture alfalfa was limited. Kung also reported that compared with untreated silage, homofermentative LAB may reduce the $\mathrm{pH}$ of silage, but the degree of reduction may be insufficient to prevent undesirable bacteria in alfalfa growth, depending on the specific situation [31,51]. Pahlow et al. considered that when LA fermentation was inadequate to rapidly decrease the $\mathrm{pH}$ of a silage system, Clostridia fermentation easily occurred [52]. Garciella is an anaerobic and thermophilic bacterial genus of the class Clostridia, and is undesirable in silage because it can lead to excessive protein degradation, DM loss, and BA production [53]. Garciella can grow in the $\mathrm{pH}$ range of 5.5-9.0, and its optimum $\mathrm{pH}$ is 7.5. However, growth of Clostridia can be completely inhibited only for $\mathrm{pH}<4.2$ [33]. Clostridia are known to be particularly sensitive to water availability, and they require wet conditions for proliferation [48]. In this study, the CK silage showed severe corruption and Garciella became the dominant genus at $60 \mathrm{~d}$, possibly due to the high moisture concentrations. Similarly, Zhang et al. found that with longer ensiling time, Garciella played a more important role in Clostridia fermentation, and that the presence of Garciella led to alfalfa being more difficult to ensile [17]. Therefore, it can be further speculated that Garciella is one of the dominant bacteria in Clostridia fermentation. Anaerosporobacter is similar to Garciella, and also belongs to class Clostridia [54]. It is speculated that Anaerosporobacter may play the same role as Garciella in silage. Compared with CK silage, the abundance of Garciella and Anaerosporobacter was significantly $(p<0.05)$ lower after adding LAB of YX, 
consistent with the lower $\mathrm{pH}$ and $\mathrm{NH}_{3}-\mathrm{N}$ concentration and absence of $\mathrm{BA}$ in $\mathrm{YX}$ silage at $60 \mathrm{~d}$.

\subsection{Relationships between Fermentation Parameters and Bacterial Community}

A Spearman's correlation heatmap (Figure 7) was used to elucidate relationships among the fermentation parameters and the microbial community. It has been reported that the plant proteases produced by plant respiration at the beginning of ensiling may be related to the synthesis of $\mathrm{NH}_{3}-\mathrm{N}$. With longer ensiling time, the synthesis of $\mathrm{NH}_{3}-\mathrm{N}$ is also related to the activity of protease produced by some microorganisms $[55,56]$. In this study, the bacteria associated with $\mathrm{NH}_{3}-\mathrm{N}$ differed for different periods. $\mathrm{The}^{\mathrm{N}} \mathrm{NH}_{3}-$ $\mathrm{N}$ concentrations were significantly $(p<0.05)$ positively correlated with Lelliottia and Klebsiella at $15 \mathrm{~d}$ (both Enterobacteriaceae). It was reported that proteases produced by Enterobacteriaceae were related to synthesis of $\mathrm{NH}_{3}-\mathrm{N}$ [57]. Compared with $\mathrm{YX}$ silage, the concentration of $\mathrm{NH}_{3}-\mathrm{N}$ of $\mathrm{CK}$ silage was significantly $(p<0.05)$ higher at $60 \mathrm{~d}$, possibly because Garciella became the dominant bacteria in CK silage at that time, consistent with the significant $(p<0.05)$ positive correlation between Garciella and $\mathrm{NH}_{3}-\mathrm{N}$ at $60 \mathrm{~d}$. The appearance of Clostridia was undesirable because they can use protein and WSC to produce BA and consequently affect silage quality due to the unpleasant odor of BA [17]. A large amount of BA was detected in CK silage at $60 \mathrm{~d}$, consistent with the significant $(p<0.05)$ positive correlation of Garciella and Clostridium_sensu_stricto_18 with BA. Anaerosporobacter was also significantly $(p<0.05)$ positively correlated with $\mathrm{NH}_{3}-\mathrm{N}$ and $\mathrm{BA}$, and may have similar effects to Garciella during ensiling. Weissella was significantly $(p<0.05)$ positively correlated with BA at $60 \mathrm{~d}$, likely because BA was only detected at $60 \mathrm{~d}$ in CK silage and the relative abundance of Weissella was higher in CK than in YX silage. It was reported that the ability of Weissella for LA fermentation was lower than that of Lactobacillus [30], so CK silage with a higher $\mathrm{pH}$ than YX silage failed to inhibit undesirable microbial activity. Lactobacillus was positively correlated with LA concentration and negatively correlated with $\mathrm{pH}$, consistent with the general recognition that Lactobacillus is the main producer of LA and plays an important role in reducing $\mathrm{pH}$ during ensiling [30,46,58].

The experimental results indicate that it is important to develop high-efficiency LAB additives with strong acid production ability and the ability to effectively inhibit the growth of Enterobacteriaceae, so as to improve the quality of alfalfa silage.

\section{Conclusions}

In conclusion, naturally ensiled alfalfa with high moisture content was prone to rot, and the relative abundance of Enterobacter, Hafnia-Obesumbacterium, Garciella, and Anaerosporobacter showed these to be the dominant genera. Adding LAB of YX delayed the rot process to a certain extent by lowering $\mathrm{pH}$, promoting LA and AA accumulation, inhibiting BA formation, increasing the abundance of Lactobacillus, and decreasing the abundance of Garciella and Anaerosporobacter. However, the quality of silage with LAB of $\mathrm{YX}$ addition was still unsatisfactory, because the $\mathrm{pH}$ in silage was not reduced to a satisfactory value, and the growth of Enterobacter and Hafnia-Obesumbacterium could not be effectively inhibited. Thus, it is a focus to develop high-efficiency LAB additives with strong acid production ability and effective inhibition of the growth of Enterobacteriaceae in a future study.

Author Contributions: Conceptualization, S.Z.; methodology, F.Y. and Y.W. (Yuan Wang); software, S.Z.; validation, F.Y. and Y.W. (Yuan Wang); formal analysis, S.Z. and F.Y.; investigation, X.F.; resources, Y.W. (Yuan Wang) and X.F.; data curation, S.Z.; writing-original draft preparation, S.Z.; writingreview and editing, Y.W. (Yanping Wang); visualization, S.Z.; supervision, Y.W. (Yanping Wang); project administration, Y.W. (Yanping Wang); funding acquisition, Y.W. (Yanping Wang) and C.F. All authors have read and agreed to the published version of the manuscript.

Funding: This research was funded by the National Natural Science Foundation of China, grant number 31772672 and Special project on the development of emerging disciplines of Henan Academy of Agricultural Sciences, grant number 2020XK03 and 2021XK06. 
Institutional Review Board Statement: Not applicable.

Informed Consent Statement: Not applicable.

Data Availability Statement: Data are contained within the article.

Conflicts of Interest: The authors declare no conflict of interest.

\section{References}

1. Duniere, L.; Sindou, J.; Chaucheyras-Durand, F.; Chevallier, I.; Thevenot-Sergentet, D. Silage processing and strategies to prevent persistence of undesirable microorganisms. Anim. Feed Sci. Tech. 2013, 182, 1-15. [CrossRef]

2. Radovic, J.; Sokolović, D.; Marković, J. Alfalfa-most important perennial forage legume in animal husbandry. Biotechnol. Anim. Husb. 2009, 25, 465-475. [CrossRef]

3. Eikmeyer, F.G.; Kofinger, P.; Poschenel, A.; Junemann, S.; Zakrzewski, M.; Heinl, S. Metagenome analyses reveal the influence of the inoculant Lactobacillus buchneri CD034 on the microbial community involved in grass ensiling. J. Biotechnol. 2013, 167, 334-343. [CrossRef]

4. $\quad$ Nkosi, B.D.; Meeske, R.; Langa, T.; Motiang, M.D.; Modiba, S.; Mkhize, N.R. Effects of ensiling forage soybean (Glycine max (L.) Merr.) with or without bacterial inoculants on the fermentation characteristics, aerobic stability and nutrient digestion of the silage by Damara rams. Small Rumin. Res. 2016, 134, 90-96. [CrossRef]

5. Kung, L.; Stough, E.C.; McDonell, E.E.; Schmidt, R.J.; Hofherr, M.W.; Reich, L.J.; Klingerman, C.M. The effect of wide swathing on wilting times and nutritive value of alfalfa haylage. J. Dairy Sci. 2010, 93, 1770-1773. [CrossRef] [PubMed]

6. Coblentz, W.K.; Muck, R.E. Effects of natural and simulated rainfall on indicators of ensilability and nutritive value for wilting alfalfa forages sampled before preservation as silage. J. Dairy Sci. 2012, 95, 6635-6653. [CrossRef]

7. Borreani, G.; Tabacco, E.; Schmidt, R.J.; Holmes, B.J.; Muck, R.E. Silage review: Factors affecting dry matter and quality losses in silages. J. Dairy Sci. 2018, 101, 3952-3979. [CrossRef]

8. Wang, C.; He, L.W.; Xing, Y.Q.; Zhou, W.; Yang, F.Y.; Chen, X.Y.; Zhang, Q. Effects of mixing Neolamarckia cadamba leaves on fermentation quality, microbial community of high moisture alfalfa and stylo silage. Microb. Biotechnol. 2019, 12, 869-878. [CrossRef] [PubMed]

9. Colombari, G.; Borreani, G.; Crovetto, G.M. Effect of ensiling alfalfa at low and high dry matter on production of milk used to make Grana cheese. J. Dairy Sci. 2001, 84, 2494-2502. [CrossRef]

10. Franco, R.T.; Buffiere, P.; Bayard, R. Optimizing storage of a catch crop before biogas production: Impact of ensiling and wilting under unsuitable weather conditions. Biomass. Bioenerg. 2017, 100, 84-91. [CrossRef]

11. Muck, R.E. Factors Influencing Silage Quality and Their Implications for Management. J. Dairy Sci. 1988, 71, 2992-3002. [CrossRef]

12. Muck, R.E.; Nadeau, E.M.G.; McAllister, T.A.; Contreras-Govea, M.C.; Santos, M.C.; Kung, L. Silage review: Recent advances and future uses of silage additives. J. Dairy Sci. 2018, 101, 3980-4000. [CrossRef] [PubMed]

13. Liu, Q.H.; Dong, Z.H.; Shao, T. Effect of additives on fatty acid profile of high moisture alfalfa silage during ensiling and after exposure to air. Anim. Feed Sci. Tech. 2018, 236, 29-38. [CrossRef]

14. Yuan, X.J.; Wen, A.Y.; Wang, J.; Desta, S.T.; Dong, Z.H.; Shao, T. Effects of four short-chain fatty acids or salts on fermentation characteristics and aerobic stability of alfalfa (Medicago sativa L.) silage. J. Sci. Food Agric. 2018, 98, 328-335. [CrossRef] [PubMed]

15. Fabiszewska, A.U.; Zielinska, K.J.; Wrobel, B. Trends in designing microbial silage quality by biotechnological methods using lactic acid bacteria inoculants: A minireview. World J. Microb. Biot. 2019, 35, 76. [CrossRef] [PubMed]

16. Tian, J.P.; Li, Z.Z.; Yu, Z.; Zhang, Q.; Li, X.J. Interactive effect of inoculant and dried jujube powder on the fermentation quality and nitrogen fraction of alfalfa silage. Anim. Sci. J. 2017, 88, 633-642. [CrossRef]

17. Zheng, M.L.; Niu, D.Z.; Jiang, D.; Zuo, S.S.; Xu, C.C. Dynamics of microbial community during ensiling direct-cut alfalfa with and without LAB inoculant and sugar. J. Appl. Microbiol. 2017, 122, 1456-1470. [CrossRef]

18. Yang, L.L.; Yuan, X.J.; Li, J.F.; Dong, Z.H.; Shao, T. Dynamics of microbial community and fermentation quality during ensiling of sterile and nonsterile alfalfa with or without Lactobacillus plantarum inoculant. Bioresour. Technol. 2019, 275, 280-287. [CrossRef]

19. Ercolini, D. PCR-DGGE fingerprinting: Novel strategies for detection of microbes in food. J. Microbiol. Meth. 2004, 56, 297-314. [CrossRef]

20. Stevenson, D.M.; Muck, R.E.; Shinners, K.J.; Weimer, P.J. Use of real time PCR to determine population profiles of individual species of lactic acid bacteria in alfalfa silage and stored corn stover. Appl. Microbiol. Biot. 2006, 71, 329-338. [CrossRef] [PubMed]

21. Johnson, H.E.; Merry, R.J.; Davies, D.R.; Kell, D.B.; Theodorou, M.K.; Griffith, G.W. Vacuum packing: A model system for laboratory-scale silage fermentations. J. Appl. Microbiol. 2005, 98, 106-113. [CrossRef] [PubMed]

22. Hoedtke, S.; Zeyner, A. Comparative evaluation of laboratory-scale silages using standard glass jar silages or vacuum-packed model silages. J. Sci. Food Agric. 2011, 91, 841-849. [CrossRef] [PubMed]

23. Ke, W.C.; Ding, W.R.; Xu, D.M.; Ding, L.M.; Zhang, P.; Li, F.D.; Guo, X.S. Effects of addition of malic or citric acids on fermentation quality and chemical characteristics of alfalfa silage. J. Dairy Sci. 2017, 100, 8958-8966. [CrossRef]

24. Broderick, G.A.; Kang, J.H. Automated Simultaneous Determination of Ammonia and Total Amino Acids in Ruminal Fluid and In Vitro Media. J. Dairy Sci. 1980, 63, 64-75. [CrossRef]

25. Zhao, S.S.; Wang, Y.P.; Yang, F.Y.; Wang, Y.; Zhang, H. Screening a Lactobacillus plantarum strain for good adaption in alfalfa ensiling and demonstrating its improvement of alfalfa silage quality. J. Appl. Microbiol. 2020, 129, 233-242. [CrossRef] 
26. Arthur Thomas, T. An automated procedure for the determination of soluble carbohydrates in herbage. J. Sci. Food Agric. 1977, 28, 639-642. [CrossRef]

27. Playne, M.J.; McDonald, P. The buffering constituents of herbage and of silage. J. Sci. Food Agric. 1966, 17, 264-268. [CrossRef]

28. Van Soest, P.J.; Robertson, J.B.; Lewis, B.A. Methods for Dietary Fiber, Neutral Detergent Fiber, and Nonstarch Polysaccharides in Relation to Animal Nutrition. J. Dairy Sci. 1991, 74, 3583-3597. [CrossRef]

29. Yang, F.Y.; Wang, Y.P.; Zhao, S.S.; Wang, Y. Lactobacillus plantarum Inoculants Delay Spoilage of High Moisture Alfalfa Silages by Regulating Bacterial Community Composition. Front. Microbiol. 2020, 11, 1989. [CrossRef]

30. Cai, Y.; Benno, Y.; Ogawa, M.; Ohmomo, S.; Kumai, S.; Nakase, T. Influence of Lactobacillus spp. from an inoculant and of Weissella and Leuconostoc spp. from forage crops on silage fermentation. Appl. Environ. Microb. 1998, 64, 2982-2987. [CrossRef] [PubMed]

31. Liu, Q.H.; Li, J.F.; Zhao, J.; Wu, J.X.; Shao, T. Enhancement of lignocellulosic degradation in high-moisture alfalfa via anaerobic bioprocess of engineered Lactococcus lactis with the function of secreting cellulase. Biotechnol. Biofuels 2019, 12, 88. [CrossRef]

32. Wang, S.R.; Yuan, X.J.; Dong, Z.H.; Li, J.F.; Shao, T. Effect of ensiling corn stover with legume herbages in different proportions on fermentation characteristics, nutritive quality and in vitro digestibility on the Tibetan Plateau. Grassl Sci. 2017, 63, 236-244. [CrossRef]

33. McDonald, P.; Henderson, A.R.; Heron, S.J.E. The Biochemistry of Silage; Chalcombe Publications: Marlow, UK, 1991.

34. Su, R.N.; Ni, K.K.; Wang, T.W.; Yang, X.P.; Zhang, J.; Liu, Y.Y.; Shi, W.X.; Yan, L.; Jie, C.; Zhong, J. Effects of ferulic acid esteraseproducing Lactobacillus fermentum and cellulase additives on the fermentation quality and microbial community of alfalfa silage. PeerJ 2019, 7, e7712. [CrossRef]

35. Kung, L.; Shaver, R. Interpretation and use of silage fermentation analysis reports. Focus Forage 2001, 13, 20-28.

36. Tao, L.; Guo, X.S.; Zhou, H.; Undersander, D.J.; Nandety, A. Short communication: Characteristics of proteolytic activities of endoand exopeptidases in alfalfa herbage and their implications for proteolysis in silage. J. Dairy Sci. 2012, 95, 4591-4595. [CrossRef] [PubMed]

37. Ni, K.K.; Wang, F.F.; Zhu, B.G.; Yang, J.X.; Zhou, G.A.; Pan, Y.; Tao, Y.; Zhong, J. Effects of lactic acid bacteria and molasses additives on the microbial community and fermentation quality of soybean silage. Bioresour. Technol. 2017, 238, 706-715. [CrossRef] [PubMed]

38. Ni, K.K.; Zhao, J.Y.; Zhu, B.G.; Su, R.N.; Pan, Y.; Ma, J.K.; Zhou, G.A.; Tao, Y.; Liu, X.R.; Zhong, J. Assessing the fermentation quality and microbial community of the mixed silage of forage soybean with crop corn or sorghum. Bioresour. Technol. 2018, 265, 563-567. [CrossRef] [PubMed]

39. Ennahar, S.; Cai, Y.M.; Fujita, Y. Phylogenetic diversity of lactic acid bacteria associated with paddy rice silage as determined by $16 \mathrm{~S}$ ribosomal DNA analysis. Appl. Environ. Microb. 2003, 69, 444-451. [CrossRef]

40. Namihira, T.; Shinzato, N.; Akamine, H.; Maekawa, H.; Matsui, T. Influence of nitrogen fertilization on tropical-grass silage assessed by ensiling process monitoring using chemical and microbial community analyses. J. Appl. Microbiol. 2010, 108, 1954-1965. [CrossRef] [PubMed]

41. Ma, S.S.; Fang, C.; Sun, X.X.; Han, L.J.; He, X.Q.; Huang, G.Q. Bacterial community succession during pig manure and wheat straw aerobic composting covered with a semi-permeable membrane under slight positive pressure. Bioresource Technol. 2018, 259, 221-227. [CrossRef] [PubMed]

42. Bao, W.; Mi, Z.; Xu, H.; Zheng, Y.; Kwok, L.Y.; Zhang, H.; Zhang, W. Assessing quality of Medicago sativa silage by monitoring bacterial composition with single molecule, real-time sequencing technology and various physiological parameters. Sci. Rep. 2016, 6, 28358. [CrossRef]

43. Keshri, J.; Chen, Y.R.; Pinto, R.; Kroupitski, Y.; Weinberg, Z.G.; Sela, S. Microbiome dynamics during ensiling of corn with and without Lactobacillus plantarum inoculant. Appl. Microbiol. Biot. 2018, 102, 4025-4037. [CrossRef]

44. Yang, J.; Cao, Y.; Cai, Y.; Terada, F. Natural populations of lactic acid bacteria isolated from vegetable residues and silage fermentation. J. Dairy Sci. 2010, 93, 3136-3145. [CrossRef]

45. Filya, I.; Muck, R.E.; Contreras-Govea, F.E. Inoculant effects on alfalfa silage: Fermentation products and nutritive value. J. Dairy Sci. 2007, 90, 5108-5114. [CrossRef]

46. Wang, S.; Sun, Y.; Zhao, J.; Dong, Z.; Li, J.; Nazar, M.; Shao, T. Assessment of inoculating various epiphytic microbiota on fermentative profile and microbial community dynamics in sterile Italian ryegrass. J. Appl. Microbiol. 2020, 129, 509-520. [CrossRef]

47. Amir, A.; Zeisel, A.; Zuk, O.; Elgart, M.; Stern, S.; Shamir, O.; Turnbaugh, P.J.; Soen, Y.; Shental, N. High-resolution microbial community reconstruction by integrating short reads from multiple 16S rRNA regions. Nucleic Acids. Res. 2013, 41, e205. [CrossRef] [PubMed]

48. Yuan, X.J.; Dong, Z.H.; Li, J.F.; Shao, T. Microbial community dynamics and their contributions to organic acid production during the early stage of the ensiling of Napier grass (Pennisetum purpureum). Grass Forage Sci. 2020, 75, 37-44. [CrossRef]

49. Pereira, O.G.; Rocha, K.D.; de Luces Fortes Ferreira, C.L. Chemical composition, characterization, and population of microorganisms on elephantgrass "Cameroon" (Pennisetum purpureum, Schum) and its silages. Rev. Bras. Zootec. 2007, 36, 1742-1750. [CrossRef]

50. Guo, L.N.; Yao, D.D.; Li, D.X.; Lin, Y.L.; Bureenok, S.; Ni, K.K.; Yang, F.Y. Effects of Lactic Acid Bacteria Isolated From Rumen Fluid and Feces of Dairy Cows on Fermentation Quality, Microbial Community, and in vitro Digestibility of Alfalfa Silage. Front. Microbiol. 2020, 10, 2998. [CrossRef] [PubMed] 
51. Kung, L. Silage additives: Where are we going? In Proceedings of the XVII International Silage Conference, Piracicaba, São Paulo, Brazil, 1-3 July 2015; pp. 1-3.

52. Pahlow, G.; Muck, R.E.; Driehuis, F.; Elferink, S.J.W.H.O.; Spoelstra, S.F. Microbiology of Ensiling. Agronomy 2003, 42, 31-94. [CrossRef]

53. Miranda-Tello, E.; Fardeau, M.L.; Sepúlveda, J.; Fernández, L.; Cayol, J.L.; Thomas, P.; Ollivier, B. Garciella nitratireducens gen. nov., sp. nov., ananaerobic, thermophilic, nitrate- and thiosulfate-reducing bacterium isolated from an oilfield separator in the Gulf of Mexico. Int. J. Syst. Evol. Microbiol. 2003, 53, 1509-1514. [CrossRef] [PubMed]

54. Jeong, H.; Lim, Y.W.; Yi, H.; Sekiguchi, Y.; Kamagata, Y.; Chun, J. Anaerosporobacter mobilis gen. nov., sp nov., isolated from forest soil. Int. J. Syst. Evol. Microbiol. 2007, 57, 1784-1787. [CrossRef] [PubMed]

55. Heron, S.J.E.; Wilkinson, J.F.; Duffus, C.M. Enterobacteria associated with grass and silages. J. Appl. Bacteriol. 1993, 75, 13-17. [CrossRef]

56. Heinritz, S.N.; Martens, S.D.; Avila, P.; Hoedtke, S. The effect of inoculant and sucrose addition on the silage quality of tropical forage legumes with varying ensilability. Anim. Feed Sci. Technol. 2012, 174, 201-210. [CrossRef]

57. Östling, C.; Lindgren, S. Influences of enterobacteria on the fermentation and aerobic stability of grass silages. Grass Forage Sci. 2006, 50, 41-47. [CrossRef]

58. Yang, F.Y.; Zhao, S.S.; Wang, Y.; Fan, X.M.; Wang, Y.P.; Feng, C.S. Assessment of Bacterial Community Composition and Dynamics in Alfalfa Silages with and without Lactobacillus plantarum Inoculation Using Absolute Quantification 16S rRNA Sequencing. Front. Microbiol. 2021, 11, 629894. [CrossRef] 